XYEOLOGICAL SURVEY CIRCULAR 137

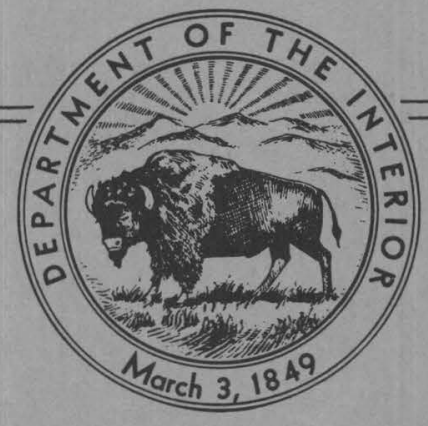

Octoher 1951

\title{
URANIFEROUS QUARTZITE, RED BLUFF PROSPECT GILA COUNTY, ARIZONA
}

\author{
By \\ E. P. Kaiser
}


UNITED STATES DEPARTMENT OF THE INTERIOR

Oscar L. Chapman, Secretary

GEOLOGICAL SURVEY

W. E. Wrather, Director

Washington, D. C.

Free on application to the Geological Survey, Washington 25, D. C. 


\section{CONTENTS}

Page

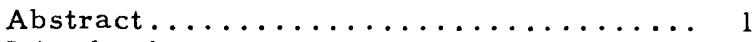

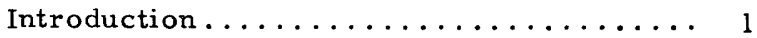

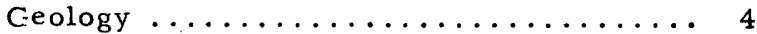

General geology ................ 4

Lncal stratigraphy ............... 4

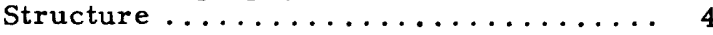

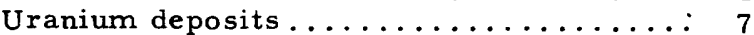

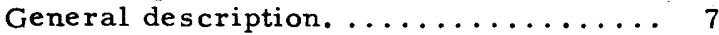

Upper favorable layer ............. 7

East wall of Warm Creek Canyon..... 7
Cut No. $1 \ldots \ldots \ldots \ldots \ldots \ldots . . \ldots \ldots$

Lower favorable layer ................. 7

West rim of Warm Creek Canyon ..... 7

Northwest of cut No. 1............ 8

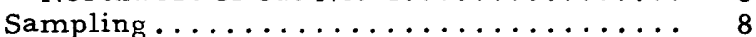





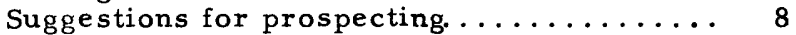

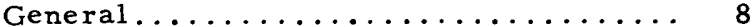

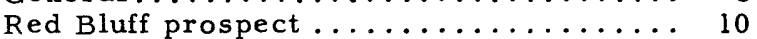

References cited........................ 10

\section{ILLUSTRATIONS}

Page

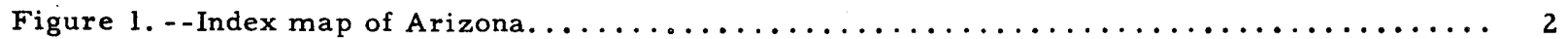

2. - Generalized geologic map of Sierra Ancha-Salt River region ..............

3. - Stratigraphic column of upper part of Dripping Spring quartzite..............

4. - -Diagrammatic cross-section showing major structures at Red Bluff prospect ..... 6

Plate 1.--Geologic map and section of central part of Red Bluff prospect ...... Inside back cover

TABLES Page

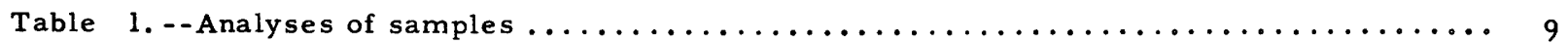




\title{
URANIFEROUS QUARTZITE, RED BLUFF PROSPECT GILA COUNTY, ARIZONA
}

\author{
By E. P. Kaiser
}

\section{ABSTRACT}

Radioactive zones are present in the upper silty part of the pre-Cambrian Dripping Spring quartzite at the Red Bluff prospect, Gila County, Arizona. The prospect is in the $\mathrm{SEl} / 4 \mathrm{sec} .31$, T. 5 N., R. $14 \mathrm{E}$, , at the southern end of the Sierra Ancha area and 12 miles northeast of Roosevelt Dam.

Stratigraphic control of the radioactive zones is indicated by the restriction of the zones to two layers, each about $20 \mathrm{ft}$ thick. The zones are spatially associated in part with a diabase dike that occupies a fault and in part with a thick diabase sill.

The principal uranium mineral disseminated through the rock in these zones has not been identified definitely, although minor quantities of secondary uranium minerals were observed. The results of scintillometer traverses and radiometric analyses indicate that the deposits probably contain an average of 0.026 percent uranium. Some black streaks and some fractures contain a higher percentage of uranium, but so far as is known the volume of such material is probably too small to affect the overall grade of the deposits.

Uranium-bearing rock occurs at four places, of which two may contain deposits of some size. At these two places the uranium bearing zones crop out along cliff faces, and further exploration would be necessary to determine the lateral extent and the possible tonnage of the zones.

Additional uranium-bearing zones might be found by prospecting the upper silty member of the Dripping Spring quartizite, especially near faults and dikes.

\section{INTRODUCTION}

The Red Bluff prospect, in Central Arizona, contains radioactive zones in two layers of quartzite of pre-Cambrian age. It consists of 11 unpatented claims owned by Mrs. Carl Larsen, Young Route, Globe, Ariz. The uraniferous material was discovered in 1950 by Mr. Larsen, after samples from a thin carbonate vein at the base of the cliff were found to be slightly radioactive. Workings on the uranium deposits consist of two small cuts.
The prospect was visited briefly by $R$. J. Wright of the Atomic Energy Commission in the summer of 1950. Between October 9 and 20, 1950 , E. P. Kaiser and H. C. Granger of the U.S. Geological Survey studied the area, made a plane-table map (pl. 1) at the scale of 1 in. equals $100 \mathrm{ft}$, and collected samples.

Only reconnaissance geology has been done in the Sierra Ancha region, except for detailed study of some of the asbestos deposits. (Shride, A. F., Manuscript report in files, U. S. Geol. Survey).

The general geology of the region, based largely on rapid reconnaissance by Darton and others (1925), is given in the Résumé of Arizona Geology and on the State geological map, 1924, published by Arizona Bureau of Mines. Several generalized stratigraphic sections of the region are given by Ransome (1916).

The Red bluff prospect is in the SEl/4 sec. 31, T. 5 N., R. 14 E., Gila County, Arizona, at the southern end of the Sierra Ancha and 12 miles northeast of Roosevelt Dam (figs. 1 and 2 ). The prospect is 34 miles northwest of Globe on the Globe-Young highway. This highway is paved for the first 12 miles northwest of Globe; the remainder is gravel road. The nearest railroad is the Southern Pacific, at Globe and Miami. The prospect is in the northwest corner of the Rockinstraw Mountain quadrangle.

The Sierra Ancha is a rugged mountainous area north of the Salt River and south of the Mogollon Rim, the southern border of the Colorado Plateau. The altitude of the area ranges from about $2,120 \mathrm{ft}$ at Roosevelt Reservoir to $7,694 \mathrm{ft}$ at the summit of Aztec Peak. The southern rim of the high Sierra Ancha is about two miles north-northeast of the Red Bluff prospect; the white dumps of asbestos mines on the rim, at an altitude of about $6,300 \mathrm{ft}$, are visible from the road to the south.

The Red Bluff prospect is at an altitude of about $3,800 \mathrm{ft}$, above a persistent cliff of quartzite. Below this cliff irregularly dissected fans slope southwestward toward the Salt River valley and Roosevelt Reservoir. The cliff is breached by short deep canyons, and the Red Bluff area includes Warm Canyon and the slopes on either side. 


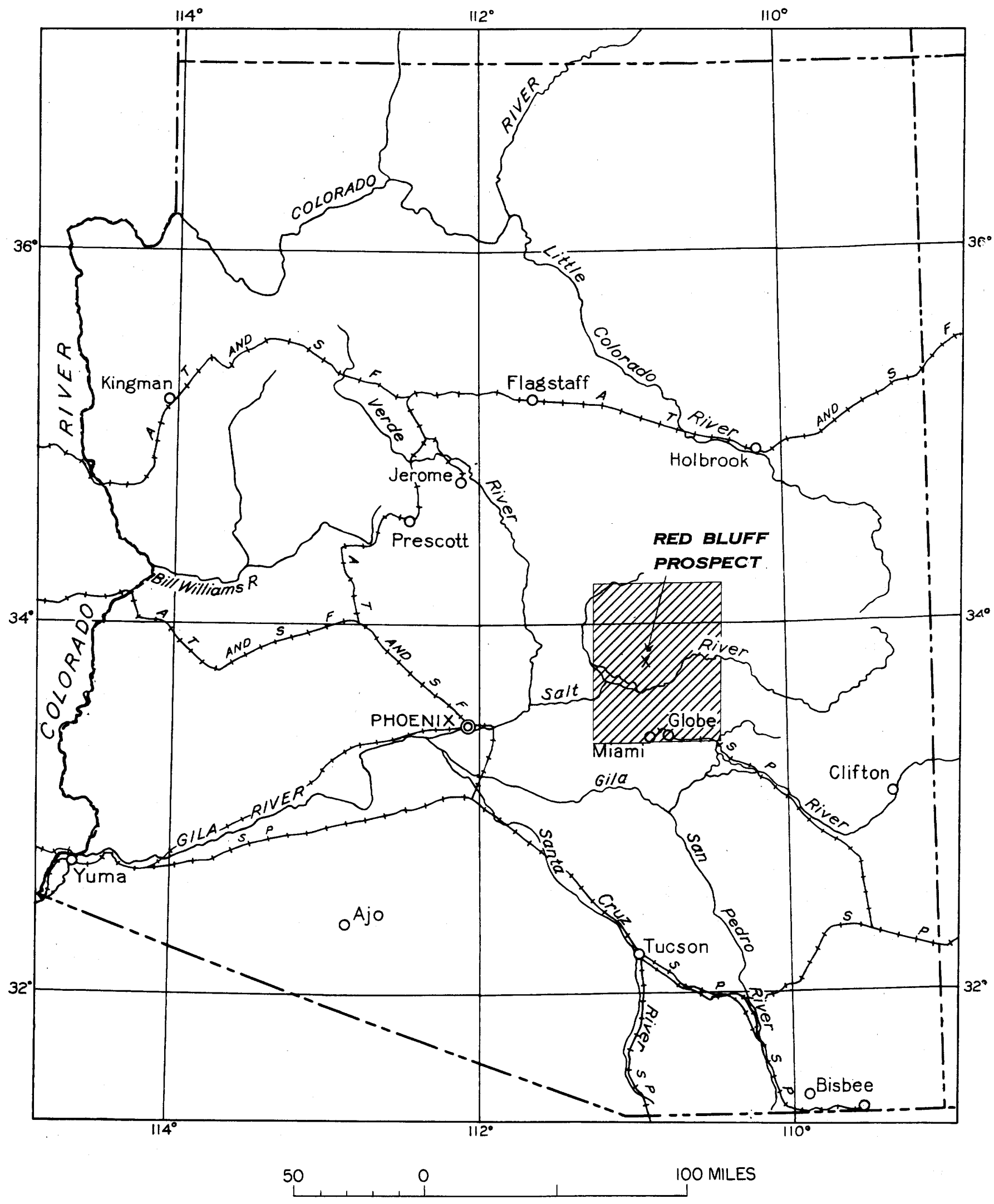

Figure 1. Index map of Arizona showing location of Red Bluff prospect and area covered by figure 2. 
1110

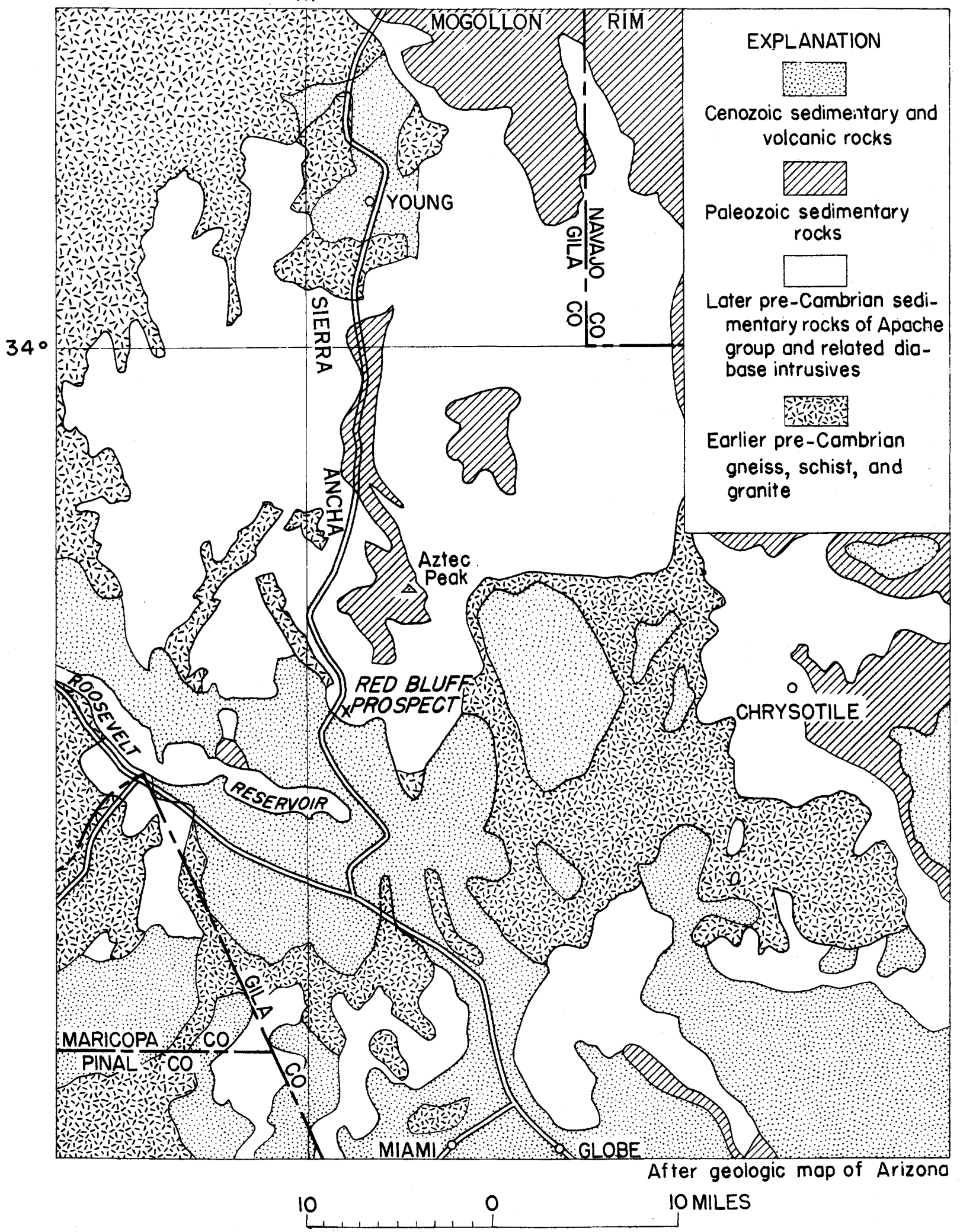

Figure 2. Generalized geologic map of Sierra Ancha-Salt River region of Arizona 


\section{GEOLOGY}

\section{General Geology}

The Sierra Ancha region (fig. 2) is underlain by sedimentary rocks, consisting of the Apache group of pre-Cambrian age and the Troy quartzite of Cambrian age; and by dikes and thick sills of diabase. Diabase is confined, for the most part, to the pre-Cambrian rocks, but a few dikes cut the Cambrian quartzite. The rocks have been faulted extensively, and locally tilted as much as $20^{\circ}$. In the foothills of the Sierra Ancha the bed rock is largely obscured by thick deposits of gravel.

The generalized columnar section for the region, according to Darton (1925) is as follows:

\section{Tertiary and Quaternary:}

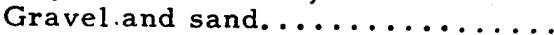

Feet

Cambrian: Troy sandstone (quartzite).

Unconformity.

Younger pre-Cambrian (Apache group):

Vesicular basalt flow .............

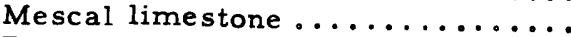

Dripping Spring quartzite ........

Barnes conglomerate............

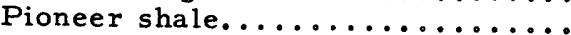

Scanlon conglomerate..........

$225-400$

$450-700$

$5-50$

$150-250$

$-30$

Unconformity.

Older pre-Cambrian: Granite and schist.

Rocks of the Apache group and the associated diabase also are exposed over a wide area east and northeast of the Sierra Ancha (fig. 2), and occur as far south as the Santa Catalina Mountains, northeast of Tucson. The Mescal limestone contains local deposits of asbestos over a large area. Asbestos is now being mined in the Sierra Ancha and along the Salt River.

\section{Local Stratigraphy}

At the Red Bluff prospect uranium-bearing rock occurs in the upper part of the Dripping Spring quartzite. Because the uranium deposits seem to be confined to two stratigraphic zones, the stratigraphic positions of uranium-bearing zones and marker beds have been determined by rapid leveling, corrected for local apparent dip along the line of measurement. The measured section is shown graphically in figure 3, and the positions of marker beds, where known are shown on the geologic map (plate 1).

The Dripping Spring quartzite consists of fineand medium-grained quartzite. The part exposed in the Red Bluff area can be divided into an upper, fine-grained member and a lower, medium-grained member. The upper member of the formation is about $360 \mathrm{ft}$ thick. In this report it is called "upper silty quartzite member" and consists almost entirely of well-cemented fine-grained, shaly and silty quartzite. The color ranges from dark gray to chalky white, but apparently it has been affected by metamor phism locally and is therefore not dependable as a stratigraphic characteristic.
The upper silty quartzite member is underlain by a light-gray or white, medium-grained, arkosic quartzite that breaks with a glassy fracture across the grains. This layer is over 100 ft thick, but its base is not exposed within the area studied. It is called the "white quartzite member" in this report. Crossbedding is common in both the white quartzite member and the upper silty quartzite member.

The upper silty quartzite member contains several marker beds that have been useful in deciphering the stratigraphy and structure. A layer of light-gray or white, medium-grained quartzite, about $50 \mathrm{ft}$ below the top of the formation, is from three to eight ieet in thickness and apparently persists over a wide area. This layer is called the "upper white quartzite marker."

A one-foot layer of very fine-grained siltstone - dark gray on fresh surfaces and weathering rusty black - about $165 \mathrm{ft}$ below the upper white quartzite marker. This layer is called the "upper black marker." It is the top of a layer about $20 \mathrm{ft}$ thick that locally is abnormally radioactive. This 20 -foot layer is called the "upper favorable layer" (fig. 3).

About $48 \mathrm{ft}$ below the upper black marker is a discontinuous 4-inch layer of similar blackweathering siltstone. This layer is called the "lower black marker." It is present locally south of the cut in the canyon, along the west rim of the canyon, and on the western side of the low hill west of the canyon. This marker is at the top of a 20 -foot layer that is locally radioactive, and is called the "lower favorable layer."

The top of the white quartzite member is stratigraphically about $95 \mathrm{ft}$ below the lower black marker, and about $360 \mathrm{ft}$ below the top of the formation; this is the major reference horizon in determining stratigraphic position.

\section{Structure}

The sedimentary rocks in the Red Bluff area are nearly horizontal. At Warm Creek Canyon the Dripping Spring quartzite is cut by a nearly vertical diabase dike with a minimum thickness of $120 \mathrm{ft}$. Warm Creek Canyon has developed by erosion of the dike.

The Dripping Spring quartzite is offset across the dike, and is downthrown about $220 \mathrm{ft}$ on the east side of the dike, relative to the west side (see pl. 1, sect. A-A ${ }^{1}$ ). There are abundant joints in the diabase parallel to and adjacent to its contacts; but the field evidence observed did not indicate whether the dislocatinn occurred before, during, or after the intrusion of the dike.

On the east wall of Warm Creek Canyon the middle and upper parts of the Dripping Spring quartzite, and the overlying Mescal limestone, are exposed on a very steep slope. Several hundred feet above the base of the limestone is a diabase sill. Exposures to the north of the mapped area indicate that the sill coalesces with the dike (fig. 4). 


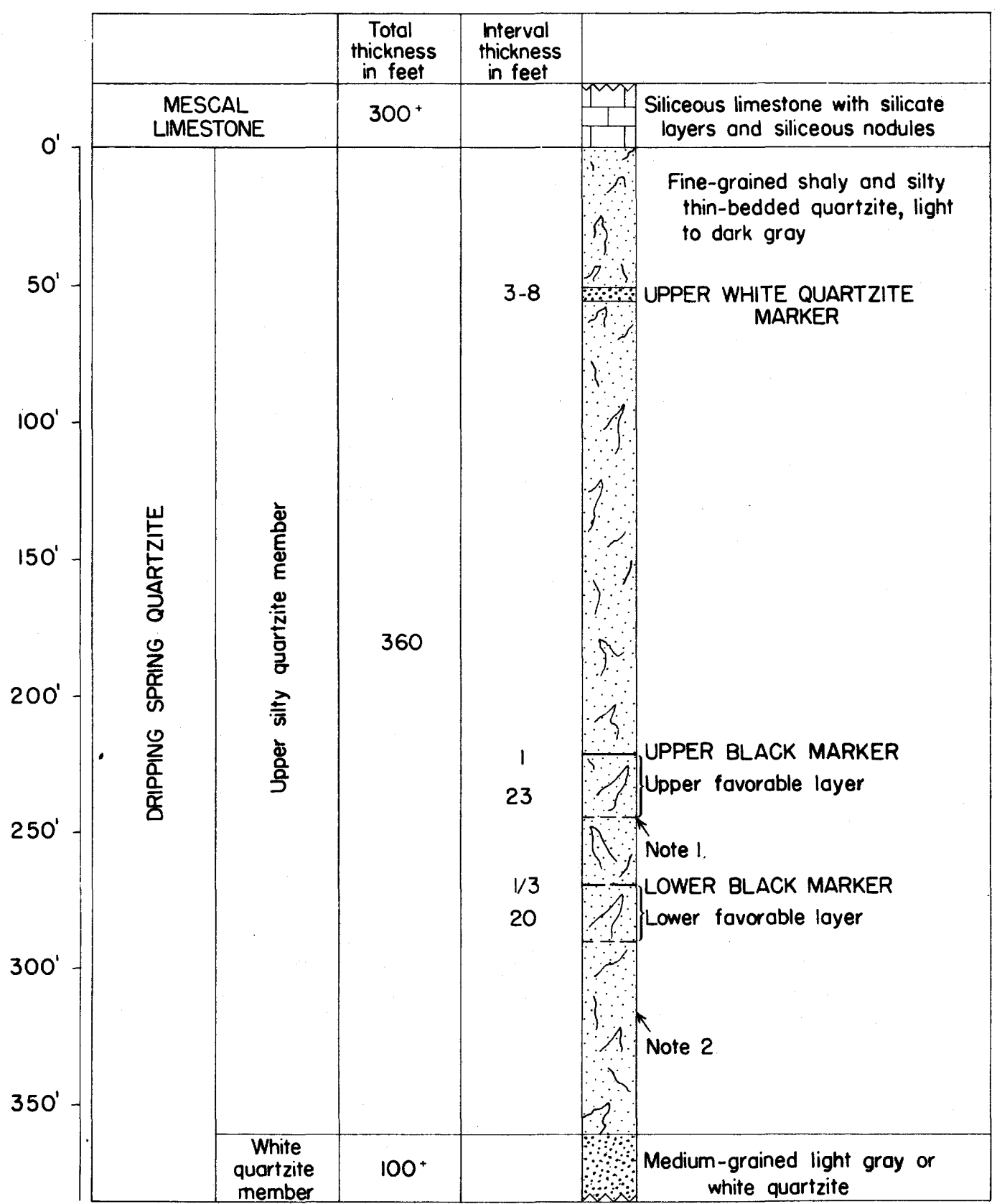

Note 1. Horizon of cuts I and 2. Also approximate horizon of intrusion of diabase sill west of Warm Creek Canyon

Note 2 Horizon of radioactive area on east rim of Parker Creek Canyon

Figure 3. Stratigraphic column of upper part of Dripping Spring quartzite at the Red Bluff prospect, Gila County, Arizona. 
On the west side of Warm Creek canyon a relatively flat erosional surface is underlain by Dripping Spring quartzite. North of the flat area a sill is exposed on a steep slope; and it is apparent that the base of the eroded part of this sill coincides approximately with the flat surface. The flat surface is therefore interpreted as a terrace produced by removal of the less resistant diabase.

Exposures in the upper part of Warm Creek Canyon indicate that the sill is at least $500 \mathrm{ft}$ thick, and that it coalesces with the dike in the canyon. The sills on the east and west sides of the canyon are thus parts of a single continuous sill (see fig. 4). The dike may occupy the channelway along which the sill material rose.

The exposed edge of the sill extends at least 5 miles northwest of the Red Bluff area, and removal of part of the sill by erosion has produced a conspicuous sloping rock terrace about onehalf mile wide.

A fault zone in the southern part of the area trends N. $65^{\circ}$ W. (pl. 1). South of the fault zone a thick layer of gravel covers the bedrock, even in the ravines, but the few available exposures suggest that the south side of the fault has moved down relative to the north side. The fault zone locally contains veins of carbonate with pyrite and reportedly some zinc, lead, gold, and silver. Several pits have been dug on these veins, and at the mouth of Warm Creek Canyon tunnels have been driven eastward and westward in the fault zone. The tunnel to the west is caved; that to the east is on the contact between shattered quartzite on the north wall and cemented gravel on the south wall.

Joints, fractures, and faults that trend N. $60^{\circ}$ to $80^{\circ} \mathrm{W}$. are present throughout the prospect area. Several small faults of this trend that offset beds of the upper silty quartzite member of the Dripping Spring quartzite can be seen on the east wall of Warm Creek Canyon. The displacement on these faults is less than three feet, and the north side invariably is moved down relative to the south side. The faults could not be shown in detail because of the scale of mapping. One of the most prominent of the faults is shown on the map (pl. 1).

On both sides of the dike, joints parallel to the dike cut the Dripping Spring quartzite. Very gentle flexures, 6 to 12 in. in wave length and a few inches in amplitude, are present locally between the joints.

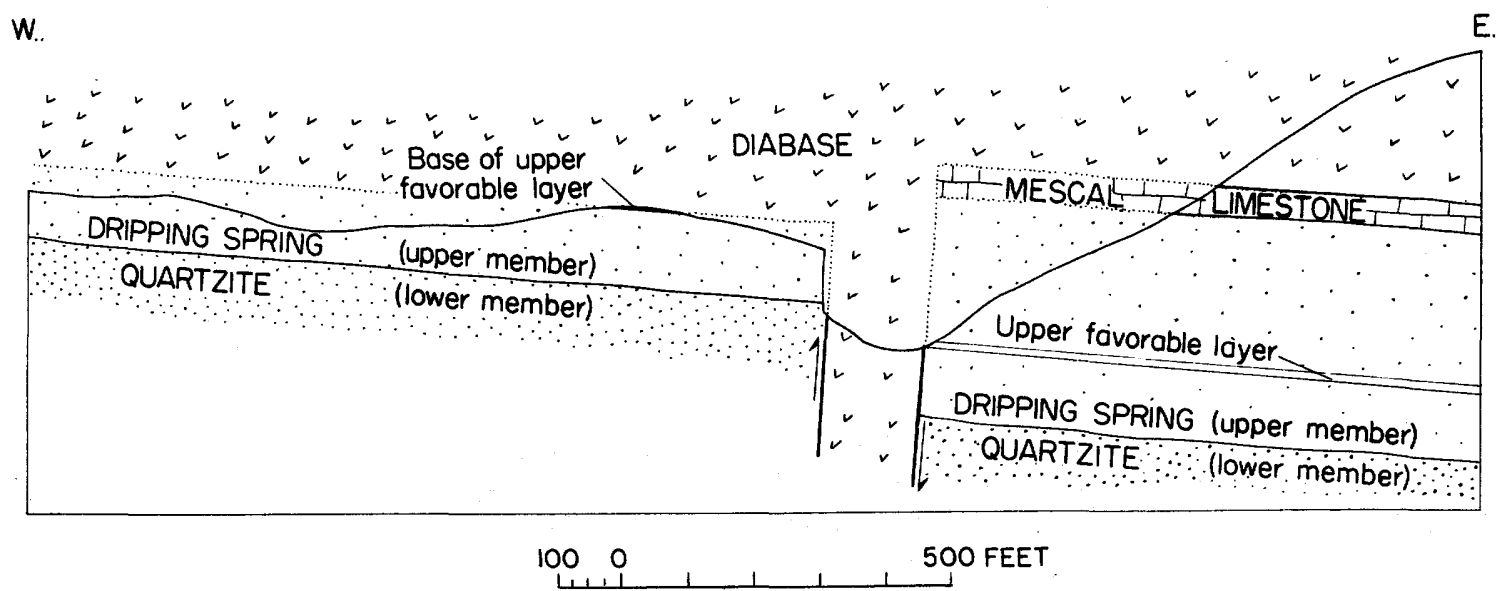

Figure 4. Diagramatic cross section showing major structures at Red Bluff prospect. 


\section{URANIUM DEPOSITS}

\section{General Description}

The abnormally radioactive material at the Red Bluff prospect is silty quartzite that contains uranium in a form as yet unidentified.

The uranium may be contained in very small grains of pitchblende. Small quantities of autunite and uranophane have been identified. (Personal communication, Lamar Evans, mineralogist, U. S. Bureau of Mines, Tucson, Arizona.) The results of assays and scintillometer traverses indicate that uranium is rather evenly distributed in the rock.

The abnormally radioactive rock is restricted to two stratigraphic layers, each about $20 \mathrm{ft}$ thick, in the upper silty quartzite member of the Dripping Spring quartzite. As only parts of these layers are abnormally radioactive, the layers are called "favorable layers", as shown in fig. 3 , and the abnormally radioactive parts are called "radioactive zones." Radioactive zones in the upper favorable layer are present on the east wall of Warm Creek Canyon and at cut No. 1 on the low hill west of the canyon. Radioactive zones in the lower favorable layer are present on the west rim of the canyon and at a spot 430 ft N. $45^{\circ} \mathrm{W}$. of cut No. 1 .

Irregular streaks of more highly radioactive material are present in the floor of cut No. 2 , in the east wall of the canyon. The streaks are a few inches or less thick, and consist of very finegrained dark gray to black silty material containing as much as 0.94 percent $\mathrm{U}_{3} \mathrm{O}_{8}$. Present exposures are insufficient to determine whether this material is abundant enough to increase the overall grade of the radioactive zone.

Highly radioactive fractures occur only within the radioactive zones. These fractures belong to the N. $60^{\circ}$ to $80^{\circ} \mathrm{W}$. system. They contain ironoxide stain and some massive limonite up to a few inches in width. Near the fractures the rock locally contains streaks and disseminated blebs of pyrite, which suggests that pyrite was the source of the iron oxide in the fractures.

The radioactive zones are in an area elongated in a northwest-southeast direction ( $\mathrm{pl}$. 1); and the similarity of this trend to that of the N. $60^{\circ}$ to $80^{\circ} \mathrm{W}$. fracture system suggests that the radioactive zones are related genetically to the fracture system.

\section{Upper Favorable Layer}

Eastwall of Warm Creek Canyon, - The upper favorable layer is exposed on the east wall of Warm Creek Canyon (pl. 1). It is abnormally radioactive in a zone passing through cut No. 2 , which is at the base of the zone. This cut, which is about $12 \mathrm{ft}$ high at the face, $4 \mathrm{ft}$ wide, and extends $13 \mathrm{ft}$ into the wall, represents the only development work done so far in this zone. The layer is capped by the upper black marker and is about $23 \mathrm{ft}$ thick.
The radioactive zone is exposed along a linear distance of about $380 \mathrm{ft}$. To the north the radioactive zone dips into the canyon floor and is covered; to the south the zone is covered by talus for several hundred feet, beyond which the favorable layer is exposed but is not abnormally radioactive.

As the outcrop of the zone is along the canyon wall, it nearly parallels the dike contact; the greatest horizontal distance from the dike is about $40 \mathrm{ft}$, at the southern end of the outcrop. There is no evidence to indicate how far the radioactive zone persists in the favorable layer into the canyon wall and away from the dike.

Cut No. 1.--Cut No. 1 (pl. 1) is near the top of the low hill west of the canyon. The cut is 8 $\mathrm{ft}$ long, $6 \mathrm{ft}$ wide, and $10 \mathrm{ft}$ deep, and exposes moderately radioactive silty quartzite that dips about $8^{\circ} \mathrm{NE}$. About $6 \mathrm{ft}$ below the upper edge of the cut is a layer of gouge several inches thick, parallel to the bedding and probably marking a bedding-plane slip. The gouge contains secondary uranium minerals - autunite and uranophane.

Stratigraphic measurements indicate that the lower part of the upper favorable layer veneers the top of the bill at cut No. 1, and that all but the base of the layer has been removed. The area covered by the layer cannot be determined because of the lack of exposures and lack of a key bed at the base of the layer, but it is estimated to be about $150 \mathrm{ft}$ in diameter.

The radioactive zone at cut No. 1 is probably $20 \mathrm{ft}$ or less below the position of the base of the diabase sill that is thought to have been present here, before erosion occurred (see fig. 4). The hill at cut No. $l$ and the gentle slope to the north are approximately at the horizon of intrusion of the sill, which crops out north of the map area.

By analogy with the relations on the east wall of the canyon, the radioactive zone at cut No. 1 probably is restricted to the favorable layer. Since most of the layer has been eroded, only a small quantity of abnormally radioactive rock is to be expected.

\section{Lower Favorable Layer}

The lower favorable layer is exposed on both sides of Warm Creek Canyon, but it is radioactive only in exposures on the western side of the canyon.

West rim of Warm Creek Canyon. - - The lower favorable layer is abnormally radioactive on the west rim of Warm Creek Canyon, about $270 \mathrm{ft}$ east-northeast of cut No. 1. The radioactive zone is about $20 \mathrm{ft}$ thick and extends along the rim for about $270 \mathrm{ft}$. Radioactivity decreases abruptly along strike to the north and south, although the favorable layer can be traced in both directions. The approximate top of the radioactive zone is the lower black marker, about $25 \mathrm{ft}$ below the base of the upper favorable layer, which is entirely eroded on the western side of the canyon except at cut No. 1. No development work has been done on the zone, and its lateral extent westward is not known. 
Northwest of cut No. 1. - - The lower favorable layer can be traced around the hill containing cut No. l, but is abnormally radioactive in only one small area, which is $430 \mathrm{ft} \mathrm{N} .45^{\circ} \mathrm{W}$. of cut No. 1 (pl. 1). From this area radioactivity decreases abruptly in all directions, as shown in plate 1. No structures were noted that might explain the localization of the radioactivity.

\section{Sampling}

Six samples were collected. Three of these consisted of selected chips; the other three consisted of chips taken along a continuous line. As no actual channel was cut, these are called "chip-line samples." The results of the analyses are given in table 1 .

The first two samples, $R B-2$ and $R B-4$, are probably representative of the radioactive zones, and indicate that the average grade of the exposed material in these layers is about 0.026 percent uranium.

Sample RB-7 is from a small area on the east wall of Warm Spring Canyon, in a horizon about $12 \mathrm{ft}$ below the base of the radioactive zone. It was selected because the scintillometer reading was slightly higher than the average outside. the radioactive zones.

Samples RB-1 and RB-5 consist of material selected from radioactive fractures, and the analyses show that these fractures locally have relatively high uranium content.

Sample $\mathrm{RB}-3$ is from a small radioactive area on the rim of Parker Creek Canyon, about 2.5 miles northwest of the Red Bluff prospect.

\section{Radiometry}

The radioactivity of rocks at the Red Bluff prospect was measured with a scintillometer (Brownell, 1950). The tests indicated that abnormal radioactivity, where present, is rather evenly distributed. The exceptions to this rule are some of the northwest-trending fractures, and the highly radioactive streaks of dark colored material found at cut No. 2 . It is noteworthy that the northwest-trending fractures are highly radioactive only within the abnormally radioactive zones, and that all fractures tested outside these zones, both in quartzite and in diabase, gave negative results.

The results of traverses in the vicinity of cut No. 1 are shown on the map (fig. 4) by means of isorads, which are lines connecting points of equal radioactivity. Normal readings ranged from 50 to 100 . Readings ranged up to 300 at cut No. 1 and decreased away from the cut. A small area $200 \mathrm{ft}$ north of the cut gave readings up to 210 . The results of radiometric traverses in Warm Creek Canyon cannot be shown on the map because of the irregular topography.

In the course of radiometric testing in the vicinity of the Red Bluff prospect, a small area of radioactivity was found on the rim of Parker Creek canyon, about 2.5 miles northwest of the Red Bluff prospect, in the center of sec. $24, \mathrm{~T}$. 5 N., R. $13 \mathrm{E}$. This area is within the McFadden
Peak quadrangle. Within an area about three feet in diameter, scintillometer readings up to 400 were noted. A sample of the rock was found to contain 0.029 percent uranium (RB-3, table 1). The rock at this locality is in approximately the same stratigraphic position as the radioactive zones at the Red Bluff prospect.

This occurrence suggests that further prospecting, guided by geological information, may discover other radioactive deposits in the Sierra Ancha region.

\section{Origin}

The even dissemination of the radioactive material in the favorable layers, and the scarcity of visible secondary minerals, indicate that the uranium is probably in its original form as deposited, and that it has not been redistributed by ground waters. The rock in the radioactive zones has been bleached and, at least in part, recrystallized; and it is doubtful that syngenetic uranium would remain in place during these changes. The deposits, therefore, are considered to be epigenetic. Since no evidence of ground-water redistribution was observed, the deposits are considered to be of hydrothermal origin.

The distribution of the deposits suggests that they are genetically related to diabase, but, as in the case of many other deposits, this relation may be structural rather than genetic. The absence of abnormal radioactivity in the diabase, and the localization of the uranium only in certain parts of the favorable layers, favor the explanation that hydrothermal solutions were controlled by structures, and by favorable host rock. In this view, the dike-fault structure was a part, perhaps an important part, of the favorable structural setting.

These deposits are reminiscent of many metallic mineral deposits that are localized in favorable stratigraphic layers in conjunction with controlling structures, and that are generally considered to be of hydrothermal origin.

\section{SUGGESTIONS FOR PROSPECTING}

\section{General}

On the basis of present knowledge of the deposits, the most favorable places to prospect for similar uranium deposits in this part of Arizona are the following:

(1) The upper silty quartzite member of the Dripping Spring quartzite, particularly the lower third of this member.

(2) Favorable rock in the vicinity of dikes and faults.

(3) Northwesterly-trending fracture zones that cut Dripping Spring quartzite.

Because some leaching of uranium has occurred at the surface, the fresh rock of a radioactive zone may be of higher grade than the outcrop. It is possible that more of the black, highly radioactive siltstone, like that at cut No. 2 may be found. 
Table 1.-- Analyses of samples

(By U. S. Geol. Survey)

\begin{tabular}{|c|c|c|c|c|}
\hline $\begin{array}{l}\text { Sample } \\
\text { number }\end{array}$ & Location & Description & $\begin{array}{l}\text { Equivalent } \\
\text { uranium } 1 / \\
\text { (Percent) }\end{array}$ & $\begin{array}{l}\text { Uranium } \\
\text { (Percent) }\end{array}$ \\
\hline $\mathrm{RB}-2$ & West rim Warm Creek Canyon. & $\begin{array}{l}\text { Chip-line sample across } 8 \mathrm{ft} \text { of radioactive } \\
\text { layer. Average meter reading } 430 .\end{array}$ & 0.037 & 0.026 \\
\hline $\mathrm{RB}-4$ & $\begin{array}{l}\text { East wall Warm Creek Canyon, } 70 \\
\text { ft north of cut No. } 2 \text {. }\end{array}$ & $\begin{array}{l}\text { Chip-line sample across } 4 \mathrm{ft} \text { of radioactive } \\
\text { layer, starting } 1 \mathrm{ft} \text { above floor. Average } \\
\text { meter reading } 450 \text {. }\end{array}$ & .028 & .027 \\
\hline $\mathrm{RB}-7$ & $\begin{array}{l}\text { East wall Warm Creek Canyon, } 70 \\
\text { ft south of cut No. } 2 \text {. }\end{array}$ & $\begin{array}{l}\text { Selected chips from area } 2 \mathrm{ft} \text { square, } 8 \mathrm{ft} \\
\text { above floor. Average meter reading } 150 .\end{array}$ & .007 & .004 \\
\hline $\mathrm{RB}-1$ & West rim Warm Creek Canyon. & $\begin{array}{l}\text { One-foot horizontal, chip-line sample across } \\
\text { fracture. Meter reading in fracture } 3000 \pm\end{array}$ & .39 & .15 \\
\hline $\mathrm{RB}-5$ & $\begin{array}{l}\text { East wall Warm Creek Canyon, } 12 \\
\text { ft north of cut No. } 2 \text {. }\end{array}$ & $\begin{array}{l}\text { Selected chips from radioactive fracture. } \\
\text { Meter readings as much as } 1500 .\end{array}$ & .23 & .22 \\
\hline $\mathrm{RB}-5$ & $\begin{array}{l}\text { Parker Creek Canyon, east rim, } \\
\text { sec. } 24, \text { T. } 5 \text { N., R. } 13 \mathrm{E} \text {. }\end{array}$ & $\begin{array}{l}\text { Single sample from area } 3 \mathrm{ft} \text { in diameter, } \\
\text { meter readings up to } 400 \text {. }\end{array}$ & .032 & .029 \\
\hline
\end{tabular}

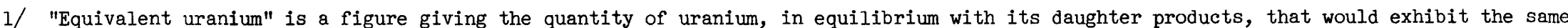
radioactivity as the sample. Radioactivity of the sample may be due to the content of all radioactive materials including, for example, members of the uranium and thorium series, and potassium. 


\section{$\underline{\text { Red Bluff Prospect }}$}

The radioactive zone at cut No. $l$ is a thin veneer of the basal part of the upper favorable layer, confined to a small area, and the material has been somewhat leached. The possibility of producing from this deposit a significant quantity of rock containing as much as 0.03 percent uranium is, therefore, small.

On the west rim and the east wall of Warm Creek Canyon, the radioactive zones crop out only along a cliff face, and the lateral extent of the zones is not known. Underground exploration work would test the lateral extent of the zones and indicate the available tonnage of uraniumbearing rock.

On the west rim of the canyon the base of the radioactive zone is less than $45 \mathrm{ft}$ deep, and drilling could easily delimit the lateral extent of the zone. The east wall of the canyon rises steeply for at least $500 \mathrm{ft}$ above the radioactive zone. Drilling would therefore be very difficult and expensive, and tunnelling into the canyon wall would be the most efficient and economical way to delimit the lateral extent of the radioactive zone. It is possible, on the basis of the genetic significance of the north-westerly vertical fractures, that the lower favorable layer may be radioactive vertically beneath the radioactive zones in the upper favorable layer. The lower layer therefore should be tested both beneath cut No. 1 and beneath cut No. 2 .

At cut No. 1 the base of the lower layer is about $45 \mathrm{ft}$ deep, and the layer could be explored easily by drilling. At cut No. 2, the base of the lower layer is also about $45 \mathrm{ft}$ deep, and the layer could be tested to some extent by holes drilled down and to the east from the canyon floor.

\section{REFERENCES CITED}

Brownell, G. M. , 1950, Radiation surveys with a scintillation counter: Econ. Geology, vol. 45, pp. 167-174

Darton, N. H. , 1925, A résumé of Arizona geology: Arizona Bur. Mines Bull. 119.

Ransome, F. L., 1916, Some Paleozoic sections in Arizona and their correlation: U. S. Geol. Survey, Prof. Paper, $98-\mathrm{K}$. 


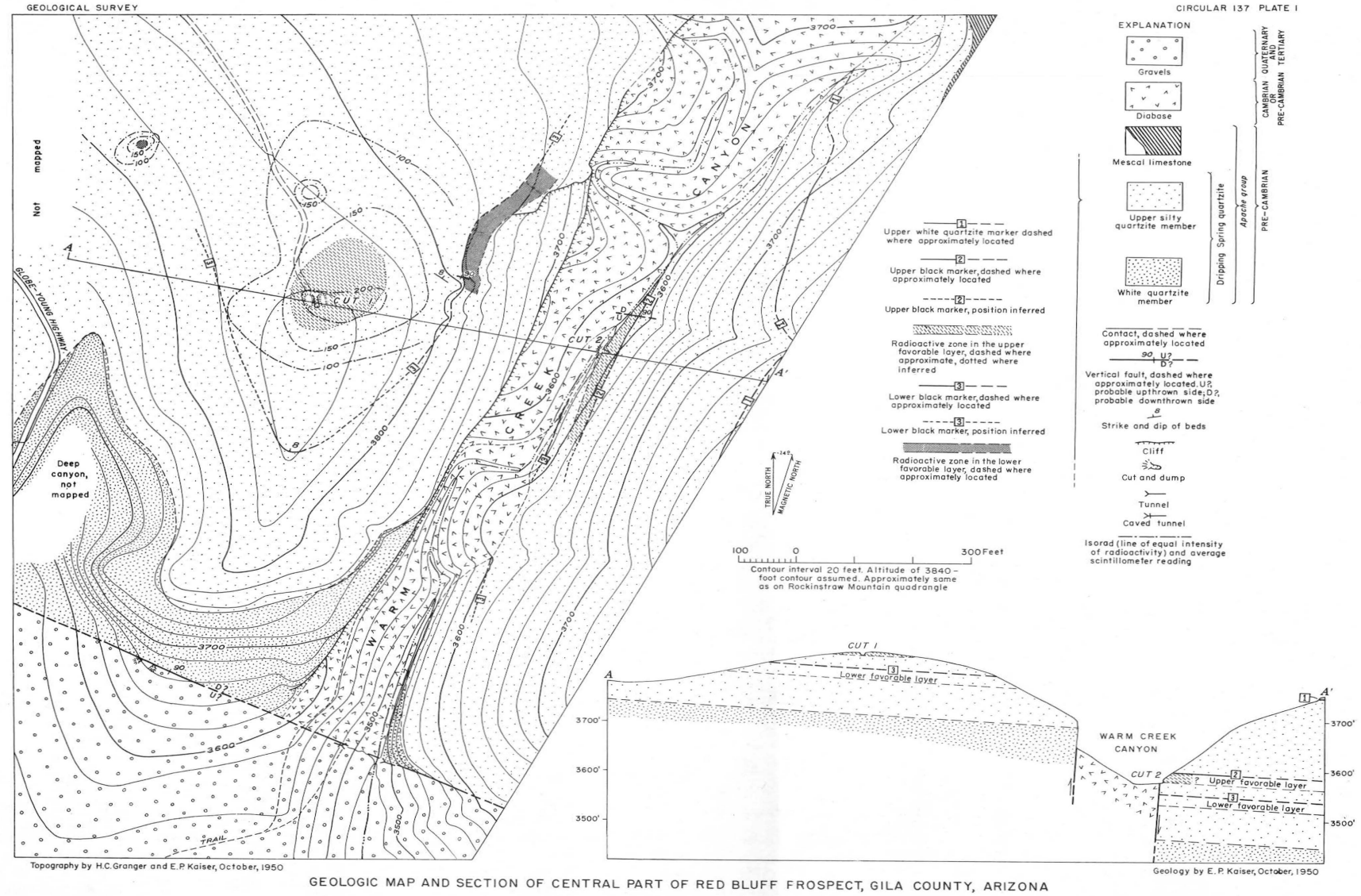

